University of Nebraska - Lincoln

DigitalCommons@University of Nebraska - Lincoln

Papers in the Earth and Atmospheric Sciences

Earth and Atmospheric Sciences, Department

2010

\title{
A New Small-Bodied Species of Palaeonictis (Creodonta, Oxyaenidae) from the Paleocene-Eocene Thermal Maximum
}

\author{
Stephen G. B. Chester \\ Yale University, stephen.chester@yale.edu \\ Jonathan I. Bloch \\ Florida Museum of Natural History, University of Florida, jbloch@flmnh.ufl.edu \\ Ross Secord \\ University of Nebraska-Lincoln, rsecord2@unl.edu \\ Doug M. Boyer \\ Brooklyn College, City University of New York, douglasmb@gmail.com
}

Follow this and additional works at: https://digitalcommons.unl.edu/geosciencefacpub

Part of the Earth Sciences Commons

Chester, Stephen G. B.; Bloch, Jonathan I.; Secord, Ross; and Boyer, Doug M., "A New Small-Bodied Species of Palaeonictis (Creodonta, Oxyaenidae) from the Paleocene-Eocene Thermal Maximum" (2010). Papers in the Earth and Atmospheric Sciences. 298.

https://digitalcommons.unl.edu/geosciencefacpub/298

This Article is brought to you for free and open access by the Earth and Atmospheric Sciences, Department of at DigitalCommons@University of Nebraska - Lincoln. It has been accepted for inclusion in Papers in the Earth and Atmospheric Sciences by an authorized administrator of DigitalCommons@University of Nebraska - Lincoln. 
Published in Journal of Mammalian Evolution 17 (2010), pp. 227-243; doi: 10.1007/s10914-010-9141-y

Copyright (c) 2010 Springer Science+Business Media, LLC. Used by permission.

Published online July 11, 2010.

\title{
A New Small-Bodied Species of Palaeonictis (Creodonta, Oxyaenidae) from the Paleocene-Eocene Thermal Maximum
}

\author{
Stephen G. B. Chester, ${ }^{1}$ Jonathan I. Bloch, ${ }^{2}$ Ross Secord, ${ }^{2,3}$ and Doug M. Boyer ${ }^{4}$ \\ 1.Department of Anthropology, Yale University, New Haven, CT, USA \\ 2. Florida Museum of Natural History, University of Florida, Gainesville, FL, USA; email jbloch@flmnh.ufl.edu \\ 3. Department of Geosciences, University of Nebraska, Lincoln, NE, USA \\ 4. Department of Anthropology and Archaeology, Brooklyn College, City University of New York, New York, NY, USA \\ Corresponding author - S.G.B. Chester, email stephen.chester@yale.edu
}

\begin{abstract}
Oxyaenid creodonts are extinct carnivorous mammals known from the Paleogene of North America, Europe, and Asia. The genus Palaeonictis is represented by three species that together span the late Paleocene to early Eocene of North America, and at least one species from the early Eocene of Europe. Previously, only a single trigonid of Palaeonictis was known from the interval encompassing the Paleocene-Eocene Thermal Maximum (PETM) in North America. We describe Palaeonictis wingi sp. nov. from the PETM in the Cabin Fork drainage, southeastern Bighorn Basin, Wyoming, based on associated right and left dentaries with $\mathrm{P}_{2}-\mathrm{M}_{2}$. Palaeonictis wingi sp. nov. is substantially smaller than the other North American congeners, making it similar in size to $P$. gigantea from the earliest Eocene of Europe and the previously described PETM specimen. We suggest that a form similar to the large-bodied late Paleocene $P$. peloria from North America gave rise to two smaller species in the earliest Eocene of North America $(P$. wingi) and Europe (P. gigantea). Palaeonictis wingi may have given rise to $P$. occidentalis following the PETM in North America. Dispersal of Palaeonictis to Europe coincided with rapid global warming of $5-10^{\circ} \mathrm{C}$ and related geographic range shifts in plants and other animals during the PETM. It has been suggested that certain mammalian lineages decreased in body size during the PETM, possibly in response to elevated temperature and/or higher $\mathrm{CO}_{2}$ levels. Results from a dietary analysis of Palaeonictis indicate that it was an omni-
\end{abstract}

vore that primarily consumed meat. This suggests that the decreased nutritious quality of vegetation caused by increased $\mathrm{CO}_{2}$ levels was not the direct contributing factor that caused body size reduction of this lineage during the PETM. Other selective pressures such as temperature, aridity, and prey size may have also contributed to the smaller body size of carnivorous mammals during this interval, although the presence of smaller species could also be explained by latitudinal range shifts of mammals during the PETM.

Keywords: Palaeonictis, Oxyaenidae, climate change,

PETM, dwarfing, orientation patch count

\section{Introduction}

Oxyaenid creodonts are a family of extinct carnivorous mammals that first appeared in the middle Tiffanian (late Paleocene) of North America (Gingerich 1980; Secord 2008). The initial radiation and major diversification of oxyaenids took place during the late Paleocene and early Eocene in North America, and smaller radiations occurred during the Eocene in Europe and Asia (Gunnell and Gingerich 1991). Palaeonictine oxyaenids include the genera Palaeonictis, Ambloctonus, Dipsalodon, and Dormaalodon (Denison 1938; Gunnell and Gin- 
gerich 1991). These taxa are characterized by heavy jaws with blunt-cusped teeth that were probably capable of bone crushing (Gunnell 1998). Palaeonictines such as Palaeonictis and Ambloctonus have been reconstructed as ambulatory with robust bodies, heavy limb bones, and short feet suggesting plantigrade postures (Denison 1938; Gunnell 1998). Like several other oxyaenids, palaeonictines are last documented at the end of the early Eocene, which may be partially due to competition with members of true Carnivora (Gunnell 1998).

The genus Palaeonictis is known from the late Paleocene to the early Eocene of North America, and from the early Eocene of Europe (Gunnell and Gingerich 1991). Palaeonictis differs from Dipsalodon in possessing an $\mathrm{M}_{2}$ that is considerably smaller than $\mathrm{M}_{1}$, a relatively smaller metaconid on $\mathrm{M}_{2}$ with a more open trigonid, and a less developed $\mathrm{P}_{4}$ talonid (Gunnell and Gingerich 1991). Rose (1981) suggested that similarities in the dentitions of Palaeonictis peloria and Dipsalodon matthewi, along with the close geographical and temporal proximity of these taxa, could indicate that Palaeonictis evolved from an early species of Dipsalodon in the late Paleocene. Although Palaeonictis is known from the latest Paleocene and early Eocene of North America, there is only one previously documented occurrence of the genus during the PETM. This specimen, an isolated trigonid, was collected from the second earliest faunal zone (Wa- 0 ) of the Wasatchian North American Land Mammal Age (NALMA) in the Clarks Fork Basin, Wyoming (Gingerich 1989).

A major faunal reorganization took place during the PETM when euprimates, perissodactyls, artiodactyls, and hyaenodontid creodonts first appeared in North America and Europe (Koch et al. 1992; Clyde and Gingerich 1998). Oxyaenid creodonts also first appeared in Europe during the PETM (Smith and Smith 2001). Abrupt global warming occurred during this interval, when global temperatures increased by $5-10^{\circ} \mathrm{C}$ (Zachos et al. 2003). The PETM is marked by a negative carbon isotope excursion (CIE) in which $\delta^{13} \mathrm{C}$ values decrease by 3 to $4 \%$ in marine carbonates, and by $5 \%$ or more in soil carbonate nodules on the continents (Thomas et al. 2002; Bowen et al. 2004; Sluijs et al. 2006). The onset of the CIE is now used to define the Paleocene-Eocene boundary, which is dated at $\sim 56 \mathrm{Ma}$ (Ogg and Smith 2004; Westerhold et al. 2009). The timing of temperature increase relative to the CIE is still a matter of debate, but some studies suggest that warming preceded the CIE by at least several thousand years (Thomas et al. 2002; Sluijs et al. 2006). The first occurrence of Perissodactyla or Artiodactyla has traditionally been used to define the beginning of the Wasatchian NALMA. However, a new faunal zone (Wa-M; see Gingerich and Smith 2006) was recently proposed marking the beginning of the Wasatchian based on the first occurrence of the condylarth
Meniscotherium. The succeeding biozone (Wa-0) is defined by the first occurrence of the perissodactyl Hyracotherium sandrae, and is the principal faunal zone of the PETM. Both Wa-M and Wa-0 begin slightly after the onset of the CIE (Bowen et al. 2001). It is unclear where the Wasatchian immigrants originated, but various dispersal routes and origination centers have been proposed (e.g., Bowen et al. 2002; Smith et al. 2006; Beard 2008; Beard and Dawson 2009).

Similarities between faunas in the earliest Wasatchian of North America and earliest "Sparnacian" (earliest Eocene of Europe; approximately equivalent in age) have long been documented (e.g., Cope 1878). There is evidence for the dispersal of oxyaenids and many other mammals from North America to Europe during the earliest Eocene (e.g., Gingerich 1989; Hooker 1998; Eberle and McKenna 2002). Approximately half of the mammalian genera known from the Wa-0 biozone also occur in the "Sparnacian" of Europe, and numerous similarities among these taxa suggest that species dispersed between North America and Europe during the PETM (see Gingerich 1989; Smith 2000; Smith et al. 2002).

The European record of oxyaenid creodonts is not as well known as in North America, but it is clear that palaeonictine and oxyaenine creodonts occurred on both continents in the earliest Eocene (Gunnell and Gingerich 1991; Smith and Smith 2001). Oxyaenids appear to have dispersed from North America to Europe during the PETM, presumably in response to global warming at high latitudes (Koch et al. 1992). The earliest occurrence of an oxyaenid in Europe is at Dormaal in Belgium (Smith and Smith 2001), a fauna that occurs within the PETM (Smith et al. 2006), strongly suggesting that oxyaenids first dispersed to Europe at this time.

The PETM fauna (Wa-0) is unique in consisting of many mammals that are considerably smaller than their latest Clarkforkian and/or later Wasatchian congeners (Gingerich 1989). There is also evidence for a decrease in the size of soil organisms during this interval (Smith et al. 2009). It has been suggested that certain Wa-0 herbivorous mammalian lineages experienced a transient decrease in body size (dwarfing) during the PETM interval as a consequence of the increase in temperature and/or elevated atmospheric $\mathrm{CO}_{2}$ levels (Gingerich 2003, 2006). Recent finds suggest that carnivorous mammals also decreased in body size during the PETM (Heinrich et al. 2008). This evidence, along with the study of environmentally driven patterns of body size change in extant mammalian carnivorans, allows for a more comprehensive evaluation of the factors that influenced the presence of smaller species during the PETM.

Here we describe a new species of Palaeonictis from the PETM in the Cabin Fork drainage, southeastern Bighorn Basin, Wyoming, based on associated right and 


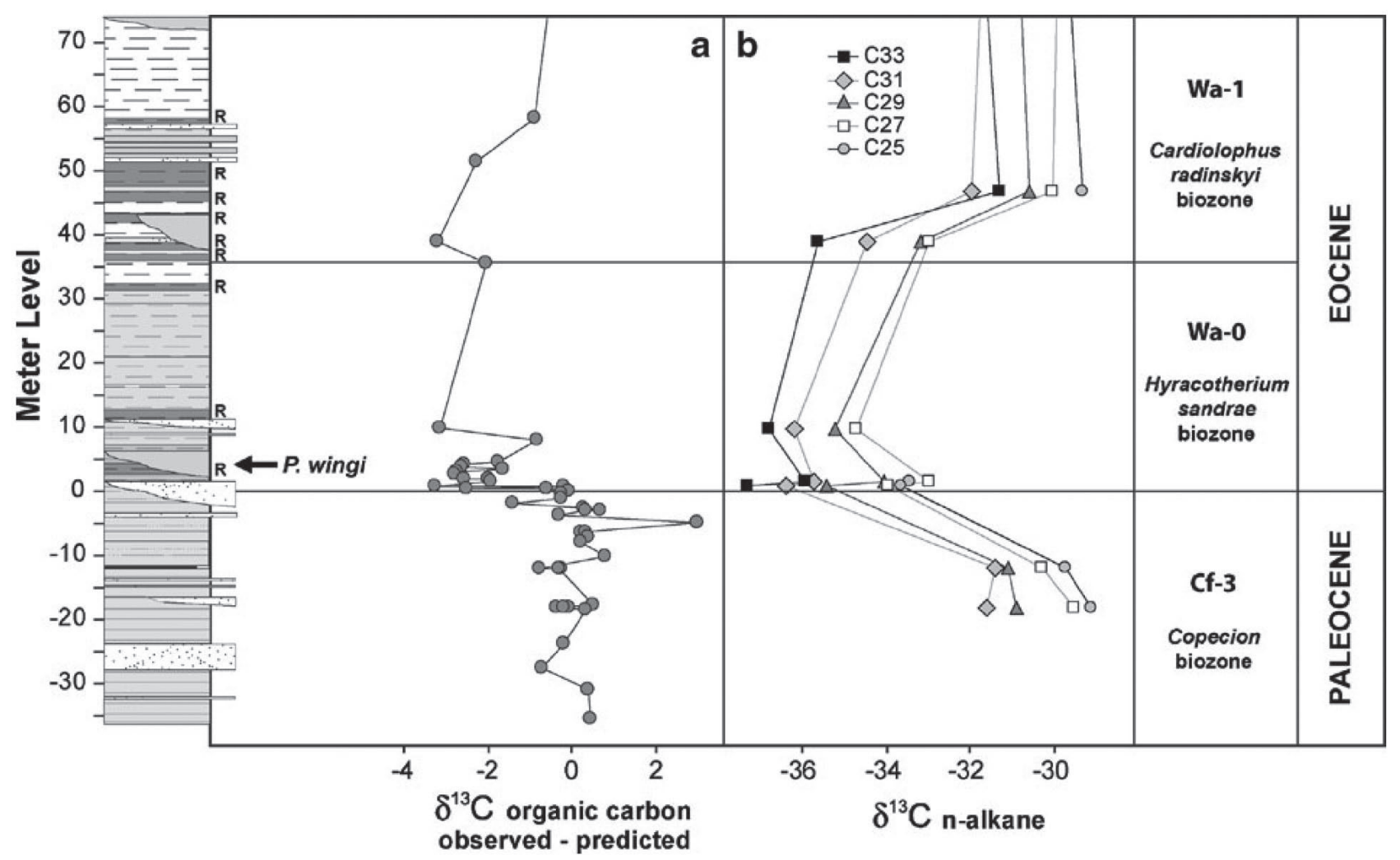

Figure 1. Composite lithostratigraphic section of Cabin Fork area showing CIE, meter levels (relative to onset of CIE), marker beds, faunal zones (Wa, Wasatchian; Cf, Clarkforkian), epochs, and stratigraphic position of Palaeonictis wingi (black arrow). (a) Difference between bulk $\delta^{13} \mathrm{C}(\mathrm{V}-\mathrm{PDB})$ for organic matter and value predicted based on weight \% organic carbon for each sample using logarithmic relationship for background conditions (Wing et al. 2005; Smith et al. 2007). (b) Compound-specific $\delta^{13} \mathrm{C}$ (VPDB) for $\mathrm{C}_{25}$ to $\mathrm{C}_{33}$ n-alkanes (Smith et al. 2007). Abbreviation: $\mathrm{R}=$ laterally continuous red beds.

left dentaries with $\mathrm{P}_{2}-\mathrm{M}_{2}$. Results from a dietary analysis of Palaeonictis and two other sympatric carnivorous mammals, Uintacyon (Miacidae, Carnivora) and Dissacus (Mesonychia), are used in part to assess which selective forces may have been responsible for the reduction of body size in some carnivorous mammals during the PETM, and phylogenetic and biogeographic relationships of Palaeonictis species are discussed.

\section{Institutional abbreviations}

AMNH American Museum of Natural History, New York, NY

ARP Argiles à lignites du Soissonnais, collections of the MNHN

IRSNB Institut Royal des Sciences Naturelles de Belgique, Brussels, Belgium

MNHN Muséum National d'Histoire Naturelle, Paris, France

UCMP University of California, Museum of Paleontology, Berkeley, CA

UF Vertebrate Paleontology Collection, Florida Museum of Natural History, Gainesville, FL
UM University of Michigan, Museum of Paleontology, Ann Arbor, MI

YPM-PU Princeton collection at Yale Peabody Museum, New Haven, CT

\section{Materials and Methods}

The holotype of the new species described here was collected in the lower Willwood Formation of the Cabin Fork drainage, southeastern Bighorn Basin, Wyoming. All reported meter levels are relative to the onset of the CIE. Local sections were measured with a Jacob's staff and sighting level, and then correlated by tracing beds with a differential Global Positioning System (dGPS) (Wing et al. 2005). Strike and dip were reconstructed from the bed traces (Wing et al. 2009). The CIE is well constrained in the Cabin Fork area by isotopic data derived from bulk organic carbon (Wing et al. 2005) and leaf-wax lipids (Smith et al. 2007) (Figure 1). Occurrence of faunas within the CIE in the Cabin Fork area is also confirmed by the recognition of numer- 
ous taxa that are only known from the Wa-0 biozone, which occurs within the CIE in the northern Bighorn Basin (Gingerich 1989; Wing et al. 2005; Yans et al. 2006).

The holotype of the new species described here was compared to the following specimens of Palaeonictis. P. peloria: YPM-PU 18077; P. occidentalis: AMNH 110, AMNH 15212, AMNH 15213, AMNH 15214, AMNH 15726, AMNH 16117, UM 77221, YPM-PU 13001, YPMPU 14677, YPM-PU 16140, YPM-PU 17842, YPM-PU 17845, YPM-PU 19901; P. gigantea: IRSNB M1355 (photograph), MNHN ARP 52; Palaeonictis sp.: UM 92889. All specimens and casts were measured with digital calipers and all measurements are presented in Table 1. Length and width measurements represent the maximum dimensions of the tooth crown. Incisor, canine, premolar, and molar tooth positions are abbreviated by the letter I, C, P, and M, respectively, followed by the corresponding tooth position number in subscript for lower teeth and superscript for upper teeth.

Using digital models of lower toothrows of Palaeonictis, Uintacyon, and Dissacus, we calculated metrics originally used to quantify features of landscapes from digital elevation models (DEM) in Geographic Information Systems (GIS). These methods have been successful in revealing dietary differences among extant mammals when applied to teeth (e.g., Evans et al. 2007). Digital models were acquired generally following procedures outlined in Boyer (2008). Casts of toothrows were made from gray-pigmented EPOTEK 301 epoxy and then microCT scanned at $35 \mathrm{mi}-$ cron $(=0.035 \mathrm{~mm})$ resolution using a Scanco Medical VivaCT 75 conebeam scanner. Energy settings were as follows: kilovolts $=70$, micro amperes $=114$, integration time $=200$. Following the methods of Evans et al. (2007), the digital tooth models generated from microCT data were converted from the Aviso ".surf" file format into digital elevation model ".grid" format and used to measure surface complexity. Complexity was quantified as an orientation patch count (OPC), which represents the number of differently oriented patches that make up the surface of a tooth or toothrow (Evans et al. 2007). We calculated OPC over the crowns of $\mathrm{M}_{1}$ and all teeth posterior to it, as done by Evans et al. (2007). One possible complication with this analysis is that Uintacyon and Dissacus have three teeth relevant to our study $\left(\mathrm{M}_{1}-\mathrm{M}_{3}\right)$, whereas Palaeonictis has only two $\left(\mathrm{M}_{1}-\mathrm{M}_{2}\right)$. However, when we performed an analysis on just two teeth of Uintacyon and Dissacus (excluding $\mathrm{M}_{3}$ ), and another using three teeth of Palaeonictis (including $\mathrm{P}_{4}$ ), we found no significant effect on measured complexity for these taxa. This is due largely to the fact that each digital model is downsampled to a resolution of 150 rows along the toothrow, regardless of how many teeth represent the toothrow.

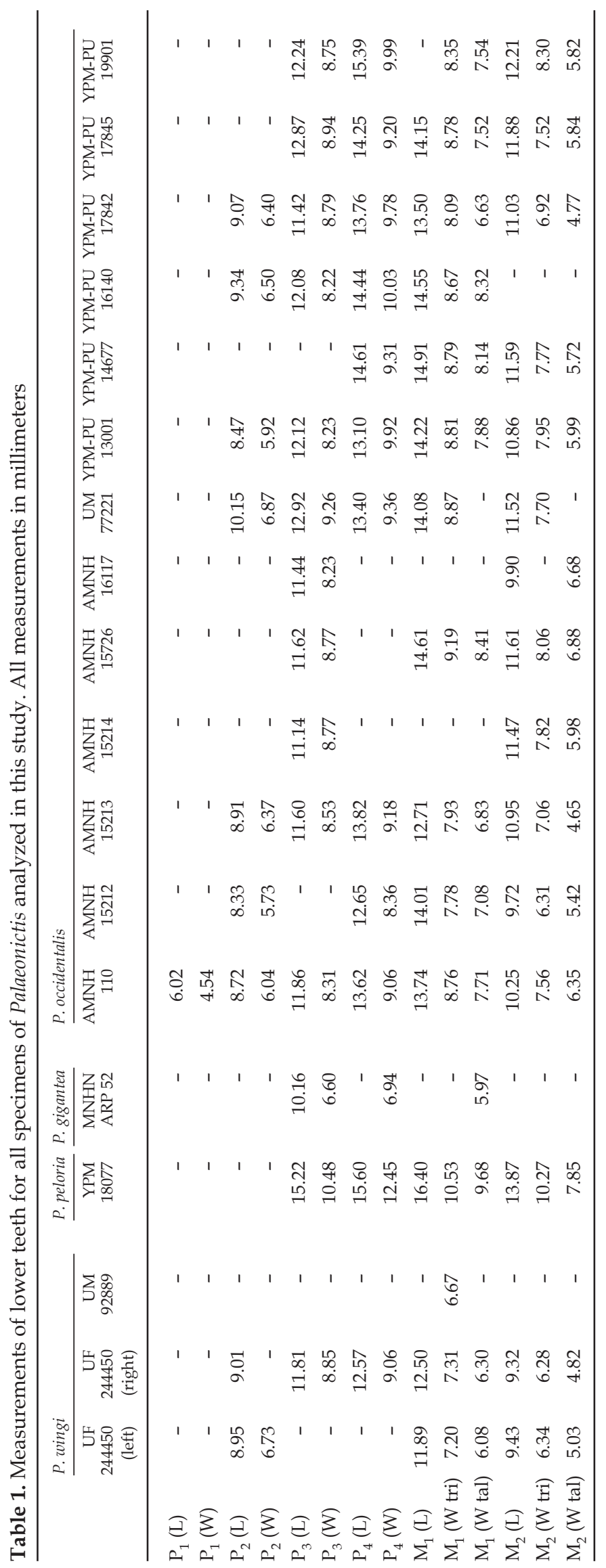



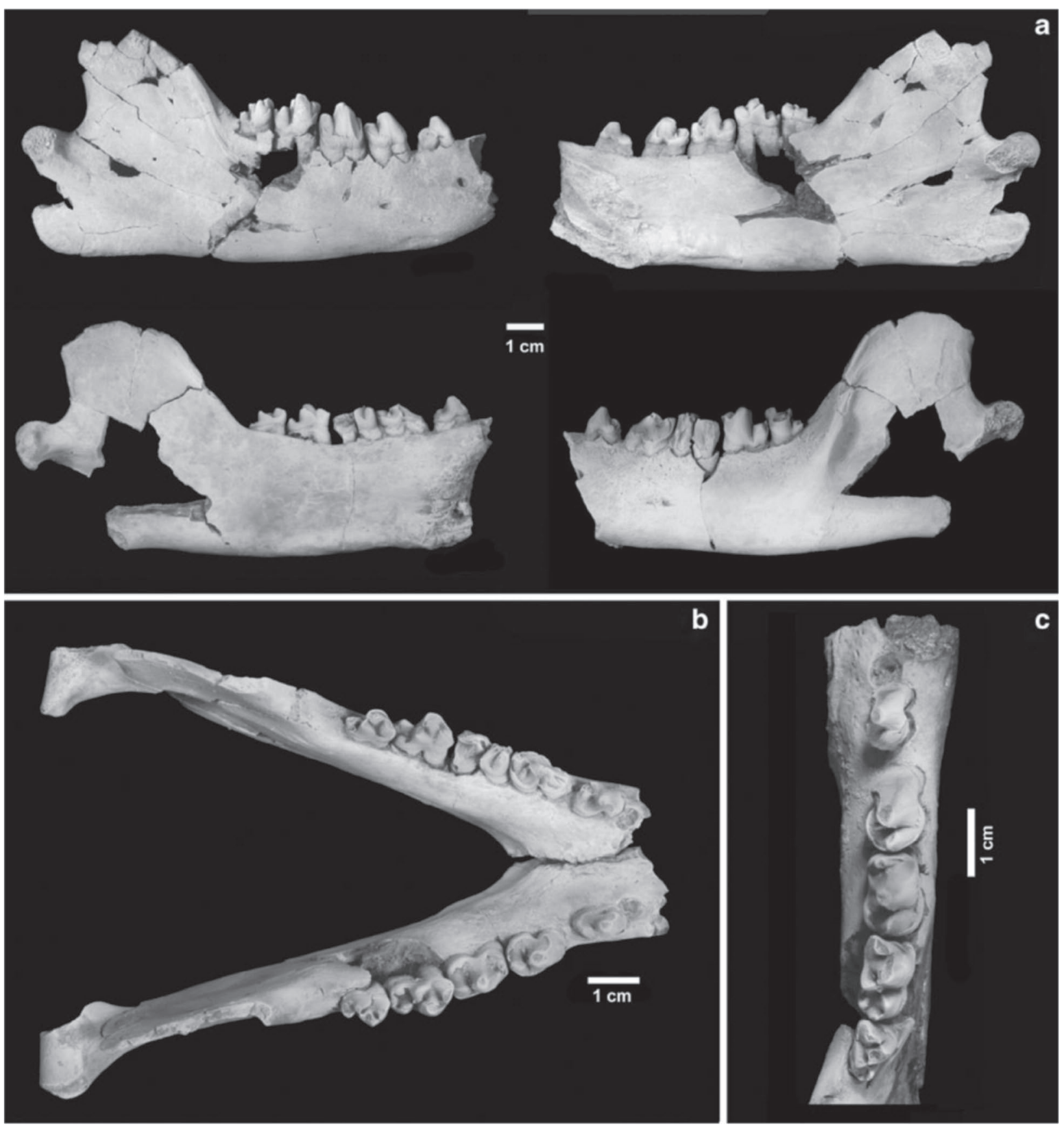

Figure 2. Holotype of Palaeonictis wingi, sp. nov. (UF 244450); associated right and left dentaries with $\mathrm{P}_{2}-\mathrm{M}_{2}$. (a) Right dentary buccal view (top left) and lingual view (top right), and left dentary lingual view (bottom left) and buccal view (bottom right). (b) Right and left dentaries in occlusal view. (c) Occlusal view of right toothrow.

These complexity measurements were compared to a dataset of 32 species of extant carnivorans that represent a wide range of diets (Evans et al. 2007). We removed Ursidae from the Evans et al. (2007) dataset because all species of ursids were outliers to the rest of the sample regardless of dietary group. Comparisons between individual species could not be accomplished using ANOVA or nonparametric equivalents, as Evans et al. (2007) only provided species means, and our sample sizes for each species are small. Instead we treated each average or single value of our fossil taxa as the "true mean" of its species. We then used a t-test to assess whether the average value of species means for particular dietary groups from Evans et al. (2007) were significantly different from the values that we generated for fossil taxa.

Only specimens that preserved all molars were used in this analysis. To assess the affect of wear on these metrics, we included four specimens of Palaeonictis occidentalis (AMNH 110, UM 77221, YPM-PU 17842, 
YPM-PU 19901) that together exhibit a large range of wear states. There was no correlation between complexity and degree of wear exhibited in these specimens, indicating differences in wear state do not substantially influence complexity values for specimens in this study. Additional specimens included in the complexity analysis are as follows: UF $244450\left(P\right.$. wingi $\mathrm{M}_{1}$ $\mathrm{M}_{2}$ ), YPM-PU 18077 (P. peloria $\mathrm{M}_{1}-\mathrm{M}_{2}$ ), YPM-PU 13295 (D. praenuntius $\mathrm{M}_{1}-\mathrm{M}_{3}$ ), YPM-PU 19597 (D. praenuntius $\mathrm{M}_{1}-\mathrm{M}_{3}$ ), UM 65473 (U. rudis $\left.\mathrm{M}_{1}-\mathrm{M}_{3}\right)$, UCMP 212722 (U. gingerichi $\mathrm{M}_{2}$ ), UCMP 216138 (U. gingerichi $\mathrm{M}_{2}$ ), UCMP 212540 (U. gingerichi $\mathrm{M}_{1}$ ). Scans of the three UCMP specimens were downloaded from Paleoview 3D, online at http://paleoview3d.marshall.edu/index.php .

\section{Systematic paleontology}

Class MAMMALIA Linnaeus, 1758

Order CREODONTA Cope, 1875

Family OXYAENIDAE Cope, 1877

Subfamily PALAEONICTINAE Denison, 1938

Palaeonictis de Blainville, 1842

Palaeonictis wingi, sp. nov. (Figure 2)

Palaeonictis sp. Gingerich, 1989: 33.

Etymology: Named for Dr. Scott L. Wing of the National Museum of Natural History in recognition of his many contributions to paleontology in the Bighorn Basin.

Holotype: UF 244450: Right dentary with $\mathrm{C}_{1}$ alveolus (broken), $\mathrm{P}_{1}$ alveolus, and crowns of $\mathrm{P}_{2}-\mathrm{M}_{2}$; left dentary with $\mathrm{P}_{1}$ alveolus, and crowns of $\mathrm{P}_{2}-\mathrm{M}_{2}$ (measurements in Table 1).

Referred specimen: UM 92889, right $\mathrm{M}_{1}$ trigonid from UM Locality SC-67.

Type-locality: Holotype was discovered by D.M.B. at UF locality WY0001, Cabin Fork drainage, southern Bighorn Basin, Wyoming.

Horizon and age: Lower Willwood Formation, Wasatchian biozone Wa-0, earliest Eocene. Found with other taxa only known from Wa-0 (Hyracotherium sandrae, Diacodexis ilicis, and Ectocion parous) at ca. 3.6 meters above the onset of the CIE as documented in the bulk-organic carbon (Wing et al. 2005).

Diagnosis: Differs from all other species of Palaeonictis in having a pronounced diastema between $\mathrm{P}_{2}$ and $\mathrm{P}_{3}$. Further differs from P. peloria and P. occidentalis in being smaller (ca. 50\% and 20\% respectively). Further differs from $P$. gigantea and P. peloria in having a more reduced $M_{2}$ relative to $M_{1}$, and in having a relatively smaller $M_{2}$ metaconid. Further differs from $P$. occidentalis in having a larger $\mathrm{P}_{3}$ relative to $\mathrm{M}_{1}$. Further differs from $P$. gigantea in having relatively wider and larger $\mathrm{P}_{3}$ without a precingulid.

Description: The holotype (UF 244450; Figure 2) preserves right and left dentaries with $\mathrm{P}_{2}-\mathrm{M}_{2}$ (left $\mathrm{P}_{3}$ and $\mathrm{P}_{4}$ are broken). The lower dental formula is (?).1.4.2. Lower incisors and canines are not preserved, but the canine alveolus on the right dentary suggests the canines were large and projecting. $\mathrm{P}_{1}$ is also not preserved, but a small alveolus (approximately $5 \mathrm{~mm}$ in diameter) just anterior to $\mathrm{P}_{2}$ on both dentaries indicates that it was a single-rooted tooth.

$\mathrm{P}_{2}$ is double-rooted, and the crown is triangular in lateral view with a primary anterior cusp and a relatively smaller posterior cusp (Figure 2). In occlusal view, the crown is hourglass-shaped with the posterior half wider than the anterior half. There is a diastema present between $\mathrm{P}_{2}$ and $\mathrm{P}_{3}$, which is slightly more pronounced on the right mandible (approximately $3.5 \mathrm{~mm}$ ).

The crown of $\mathrm{P}_{3}$ is larger than that of $\mathrm{P}_{2}$ and has a more developed posterior cusp. A small oval accessory cusp is present on the lingual side between the two major cusps. $\mathrm{P}_{3}$ has a distinct crest present from the tip of the anterior cusp to the anterolingual base of the tooth. The posterior end of the tooth is broader than the anterior end, and has buccal and lingual cingula that climb the posterior cusp.

The crown of $\mathrm{P}_{4}$ is larger than that of $\mathrm{P}_{3}$ and has a relatively more developed posterior cusp. $\mathrm{P}_{4}$ has a distinct anterior cusp (paraconid) and an entoconid. A wear facet is present on the anterobuccal side of the primary cusp (protoconid). A cingulum is present on the buccal margin of the tooth.

The crown of $\mathrm{M}_{1}$ is approximately the same length as that of $\mathrm{P}_{4}$, although it is not nearly as wide. $\mathrm{M}_{1}$ has a large protoconid, and a smaller and lower paraconid and metaconid, with the paraconid being taller and more robust than the metaconid. A small accessory cusp is present at the base of the metaconid, which almost connects with the hypoconid to form a cristid obliqua. The $\mathrm{M}_{1}$ talonid is narrower than the trigonid and all three talonid cusps are well developed and separated.

The crown of $\mathrm{M}_{2}$ is considerably smaller than that of $\mathrm{M}_{1}$. The protoconid is broken on both second molars, but it appears as though it was approximately the same height and size as the paraconid. The metaconid is smaller and shorter than the other trigonid cusps. A continuous cristid obliqua is present. The talonid is less developed and relatively narrower than that of $\mathrm{M}_{1}$. The talonid has a hypoconid and hypoconulid, but no entoconid is present.

The body of the dentary is moderately robust, and narrows mediolaterally and deepens dorsoventrally when moving posteriorly. The depth of the jaw is great- 
est below $\mathrm{M}_{2}$. Two mental foramina are preserved. The anterior foramen is located below $\mathrm{P}_{1}$ and the posterior foramen is below the posterior root of $\mathrm{P}_{3}$. The symphysis begins below the anterior root of $\mathrm{P}_{3}$. The coronoid crest is prominent and the masseteric fossa is fairly deep. The mandibular condyle is approximately at the level of the toothrow and the angular process is rounded.

Comparisons: Palaeonictis wingi, P. peloria, and P. gigantea are each represented primarily by one specimen [holotypes UF 244450 and YPM-PU 18077, and the most complete syntype MNHN ARP 52, respectively (a holotype for $P$. gigantea was never formally designated)]. Comparisons made here are based on these specimens unless otherwise noted. In order to diminish the risk of errors presented by a typological approach, features are not considered to be distinctive if they vary in P. occidentalis, which is represented here by more than a dozen specimens.

The diastema between $\mathrm{P}_{2}$ and $\mathrm{P}_{3}$ is $3.5 \mathrm{~mm}$ in the holotype of $P$. wingi. This diastema is absent in most specimens of $P$. occidentalis, and is consistently less pronounced when present. $\mathrm{P}_{2}$ is not preserved in the holotype of P. peloria, but the proximity of the anterior premolar alveoli to the $\mathrm{P}_{3}$ appears to indicate the absence of a diastema. Similarly, the crown of $\mathrm{P}_{2}$ is not preserved in a mandible of $P$. gigantea, but the distance between the $\mathrm{P}_{2}$ and $\mathrm{P}_{3}$ alveoli in the original illustrations of $P$. gigantea (de Blaineville 1842) suggests the absence of a diastema.

The crown of $\mathrm{P}_{3}$ in $P$. wingi is similar to that of $P$. peloria, but differs from that of $P$. occidentalis, in being larger relative to $M_{1}$. The relative size of $P_{3}$ is difficult to evaluate for $P$. gigantea because the most complete syntype presently only preserves $\mathrm{P}_{3}$, the talonid of $\mathrm{P}_{4^{\prime}}$ and the talonid of $\mathrm{M}_{1}$, based on an epoxy cast. However, the original illustrations of $P$. gigantea by de Blaineville (1842) include a drawing of this specimen preserving the crowns of $\mathrm{P}_{3}-\mathrm{M}_{2}$ before it was damaged. The illustration shows that $P$. gigantea is similar to $P$. wingi and $P$. peloria in possessing a $\mathrm{P}_{3}$ that is not reduced relative to $\mathrm{M}_{1}$.

The width relative to length of $P_{3}$ in $P$. wingi falls within the upper end of the range of $P$. occidentalis and, as is true for all other species of Palaeonictis; the crown of $\mathrm{P}_{3}$ is relatively wider than that of $P$. gigantea (MNHN ARP 52). P. wingi also differs from $P$. gigantea in having a larger $\mathrm{P}_{3}$ and lacking a pronounced precingulid on $\mathrm{P}_{3}$. Presence of a precingulid in $\mathrm{P}_{3}$ is variable in P. occidentalis, although it is never as pronounced as in the most complete syntype of $P$. gigantea.

The size of $P_{4}$ relative to $M_{1}$ is similar among all species of Palaeonictis. Like $\mathrm{P}_{3}$, the $\mathrm{P}_{4}$ of $P$. wingi falls in the upper end of the range of relative width for $P$. occidentalis. This may also be the case for $P$. gigantea. In MNHN ARP 52, the partial $\mathrm{P}_{4}$ appears to have been narrower than in most other specimens of Palaeonictis based on its posterior width, the position of its anterior root, and the interstitial facet on the posterior end of $P_{3}$. An isolated $\mathrm{P}_{4}$ from Dormaal (IRSNB M1355) that was attributed to $P$. gigantea by Smith and Smith (2001) appears to exhibit similar proportions to that of $P$. wingi (see Quinet 1966: Figs. 4-6, pl. 5). The $\mathrm{P}_{4}$ paraconid is proportionally smaller in $P$. wingi, relative to the other trigonid cusps, than in P. peloria, $P$. occidentalis, and P. gigantea (IRSNB M1355). A pronounced wear facet is present on the anterobuccal side of the protoconid in $P$. wingi and P. peloria, but this wear facet is absent in $P$. occidentalis and $P$. gigantea (IRSNB M1355).

The $\mathrm{M}_{1}$ area of $P$. wing $i$ is approximately $50 \%$ smaller than that in the holotype of $P$. peloria and approximately $20 \%$ smaller than the average $\mathrm{M}_{1}$ size of $P$. occidentalis (Table 1). $\mathrm{M}_{1}$ is not complete in the most complete syntype of $P$. gigantea, but the size of the $\mathrm{M}_{1}$ talonid in $P$. gigantea and $P$. wingi is virtually identical, and smaller than in the other two species. The area of $\mathrm{M}_{1}$ for $P$. wingi is smaller than that of any known $\mathrm{M}_{1}$ of $P$. occidentalis (Table 1).

Palaeonictis wingi is similar to P. occidentalis in molar proportions, but differs from $P$. gigantea and P. peloria in having a more reduced $M_{2}$ relative to $M_{1}$, and a smaller $\mathrm{M}_{2}$ metaconid. The average combined $\mathrm{M}_{1}$ and $\mathrm{M}_{2}$ length for $P$. wingi (21.6 mm), P. gigantea (19-21 mm; Denison, 1938), P. occidentalis $(\sim 25 \mathrm{~mm})$, and P. peloria $(\sim 30 \mathrm{~mm})$ suggests that $P$. wing $i$ and $P$. gigantea are similar in size to each other and smaller than the other two species.

The depth of the mandible of Palaeonictis wingi, measured on the buccal side below $\mathrm{M}_{1}$, is within the lower end of the range known for P. occidentalis. P. peloria has a deeper and more massive mandible than that of either $P$. wingi or P. occidentalis. Aside from these differences, the mandible of $P$. wing $i$ is morphologically quite similar to mandibles of the other congeneric species.

\section{Results of tooth complexity analysis}

Complexity measured by OPC (Figure 3) shows marked differences between the samples of Palaeonictis, Uintacyon, and Dissacus. Palaeonictis ( $\mathrm{n}=6$, mean $=128$, range $=113-142)$ and Uintacyon $(\mathrm{n}=2$, range $=124-140)$ are non-overlapping with Dissacus $(n=2$, range $=82$ 85) (Figure 3). The OPC of P. peloria (113) is lower than that for $P$. wingi (140) and outside the range of the sample of $P$. occidentalis $(n=4$, mean $=129$, range $=116$ 137). Uintacyon rudis has higher complexity (140) than $U$. gingerichi (124). These intrageneric interspecific differences are not likely to be significant, considering the large range of values within the four specimens of $P$. occidentalis.

Comparisons to the modified Evans et al. (2007) dataset show that toothrow OPC of Dissacus (84) is most similar to the mean value of "carnivores" (92), higher than 


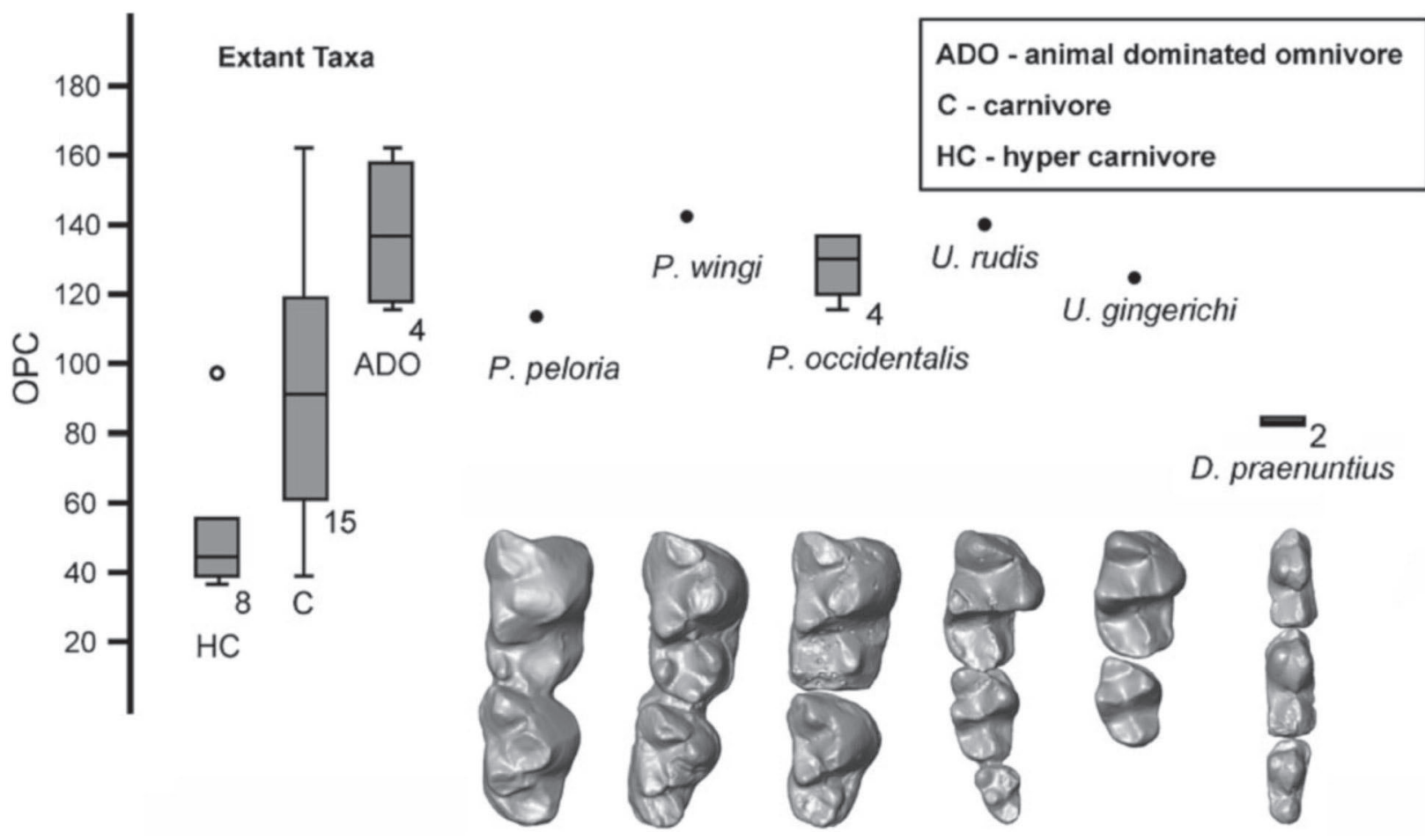

Figure 3. Comparison of orientation patch count (OPC) values for extant carnivores (HC, C, ADO)(Evans et al. 2007) with those of fossil taxa. OPC values represent number of differently oriented patches that make up tooth or toothrow surface. Horizontal lines within boxes are positioned at median value. Boxes encompass 50\% of data points; whiskers encompass $95 \%$. Data points outside of $95 \%$ brackets shown as single point outliers. Numbers to lower right of each box are sample sizes. Fossil taxa plotted to right of ranges of extant taxa. Occlusal toothrow reconstructions created using Aviso 5.0 shown directly under each respective fossil taxon value. Taxon, specimen number, and positions of toothrow reconstructions as they appear from left to right: Palaeonictis peloria, YPM-PU 18077, $\mathrm{M}_{1}-\mathrm{M}_{2} ;$ Palaeonictis wingi, UF 244450, $\mathrm{M}_{1}-\mathrm{M}_{2} ;$ Palaeonictis occidentalis, UM 77221, $\mathrm{M}_{1}-\mathrm{M}_{2} ;$ Uintacyon rudis, UM 65473, $\mathrm{M}_{1}-\mathrm{M}_{3}$; Uintacyon gingerichi, UCMP 212540, $\mathrm{M}_{1}$, and UCMP 212722, $\mathrm{M}_{2}$; Dissacus praenuntius, YPM-PU 19597, $\mathrm{M}_{1}-\mathrm{M}_{3}$. Reconstructions are not to scale.

all "hypercarnivores" except Canis lupus (97), and lower than any "animal dominated omnivore" (115-162) (Figure 3). The mean for Dissacus is significantly different from the mean of the "hypercarnivore" group $(\mathrm{n}=8, \mathrm{t}=$ $4.7, p=0.002$ ) and "animal dominated omnivore" group $(\mathrm{n}=4, \mathrm{t}=4.6, p=0.02)$, but not different from the mean of the "carnivore" group ( $\mathrm{n}=15, \mathrm{t}=0.86, p=0.4)$ using one sample t-tests in PAST. The mean of Palaeonictis (128) is closest to the mean of "animal dominated omnivores" (138), is higher than any "hypercarnivore" (3797), and overlaps with the distribution of "carnivores." The overlap is because some viverrids such as Genetta genetta and Viverra zibetha have fairly high mean OPC values (140 and 162 respectively). Furthermore, any value of an individual of Palaeonictis, or the mean for $\mathrm{Pa}$ laeonictis, is significantly different from the mean of the "hypercarnivore" group $(n=8, \mathrm{t}=11.3, P<0.001)$ and the "carnivore" group $(n=14, t=4.1, P<0.001)$, but not the "animal dominated omnivore" group $(n=4, t=0.75$, $p=0.5$ ). Like Palaeonictis, the mean OPC of Uintacyon is closest to the mean of "animal dominated carnivores," is higher than any "hypercarnivore," and overlaps with some "carnivores."

\section{Discussion}

The earliest documented occurrence of Palaeonictis is $P$. peloria from the latest Paleocene (Clarkforkian NALMA, Copecion interval zone Cf-3; Secord et al. 2006) of Wyoming (Rose 1981). Palaeonictis peloria is known only from the late Clarkforkian of North America and is represented primarily by the holotype, a left dentary with $\mathrm{P}_{3}-\mathrm{M}_{2}$ and an associated left lower canine. Palaeonictis peloria differs from all other species of Palaeonictis in being significantly larger (approximately 50\% larger than $P$. wingi and P. gigantea, and $20 \%$ larger than P. occidentalis, based on maximum dimensions of the molars). $P a$ laeonictis peloria is morphologically most similar to $P$. gigantea, and differs from $P$. wingi and $P$. occidentalis in having an $M_{2}$ that is larger, relative to $M_{1}$. This feature appears to be plesiomorphic for palaeonictines (see Gunnell and Gingerich 1991), and P. peloria is probably the most primitive species of Palaeonictis known.

Prior to the discovery of $P$. wingi, $P$. occidentalis was the only species of Palaeonictis known from the Eocene of North America. Palaeonictis occidentalis is represented by numerous specimens from the early and mid- 


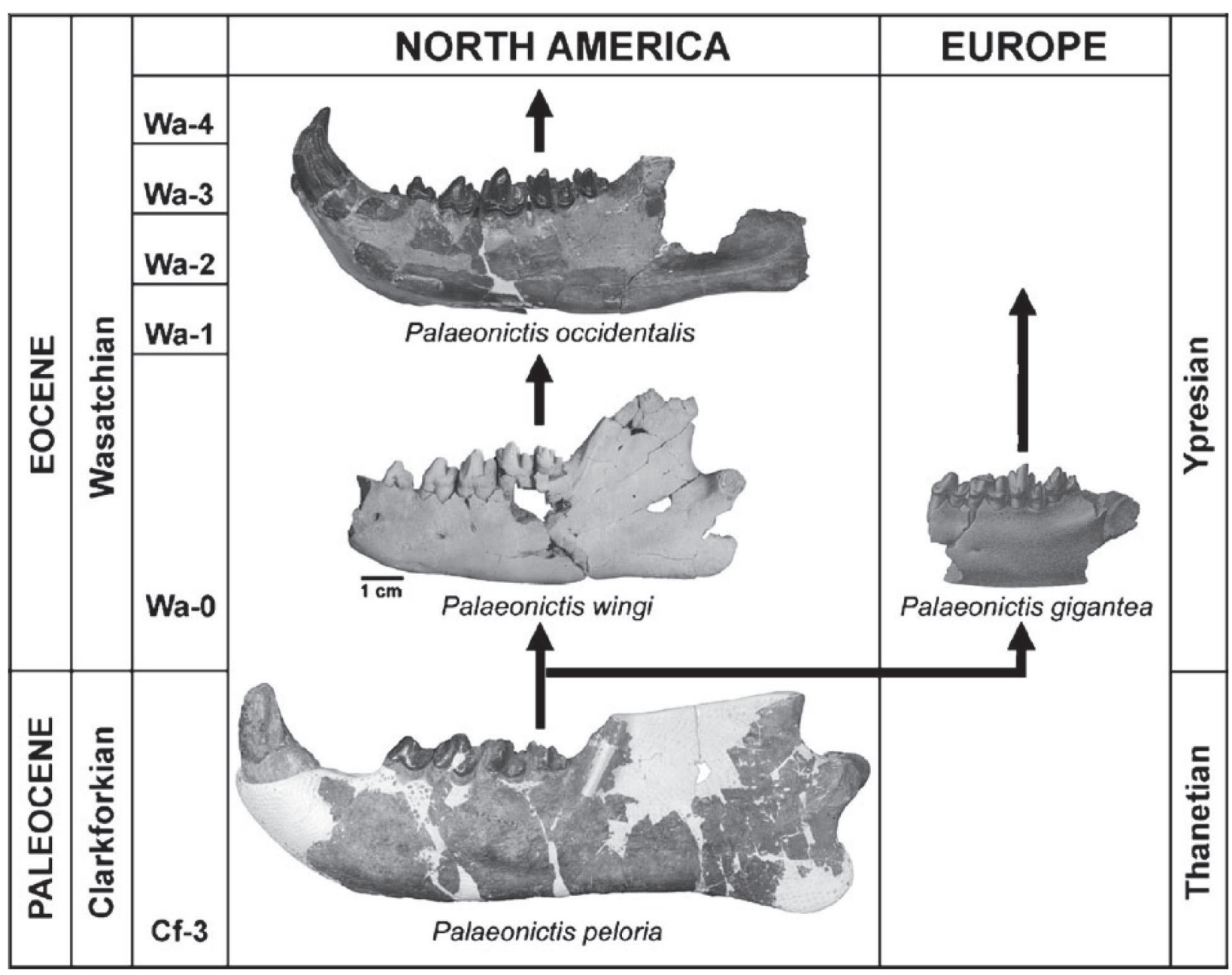

Figure 4. Geographic and temporal distribution of Palaeonictis in North America and Europe from latest Paleocene to the early Eocene. Palaeonictis peloria is represented by holotype YPM-PU 18077, Palaeonictis wingi is represented by holotype UF 244450 (reversed), Palaeonictis occidentalis is represented by holotype AMNH 110, and Palaeonictis gigantea is represented by most complete syntype MNHN ARP 52 (illustration reversed from de Blaineville 1842). Specimens are to scale. Arrows connect closely related species. Faunal zones are not to scale.

dle Wasatchian (middle Sandcouleean through middle Graybullian; faunal zones Wa-1 through Wa-4) of the Bighorn Basin. Specimens reported from the Piceance Creek Basin in Colorado (Kihm 1984) were tentatively assigned to $P$. occidentalis by Gunnell and Gingerich (1991). One specimen that includes associated edentulous maxillae and cranial fragments from the Eureka Sound Group, southern Ellesmere Island, Nunavut, Canada (Wasatchian), was identified as Palaeonictis sp. (Eberle and McKenna 2002). It is fairly similar to P. occidentalis in overall size and arrangement of tooth roots. Palaeonictis occidentalis is unique in having a reduced $\mathrm{P}_{3}$ relative to $\mathrm{M}_{1}$, and is likely the most derived species of Palaeonictis known.

Palaeonictis wingi is similar in size to $P$. gigantea from Europe, the type species of the genus. P. gigantea is known from the Lignites de Soissonais (early Ypresian) at Muirancourt (de Blaineville 1842) and from the Argile Plastique (early Ypresian) of Meudon in France (Teilhard de Chardin 1922). Palaeonictis gigantea is also known from Hoegaarden (Smith and Hooker 1996) in Belgium. In addition, a $\mathrm{P}_{4}$ (IRSNB M1355) was tentatively referred to $P$. gigantea from Dormaal, Belgium (Smith and Smith 2001), a locality in the PETM (Smith et al. 2006). However, it is smaller than the $\mathrm{P}_{4}$ in the syntype of $P$. gigantea, and may represent a new species (Smith and Smith 2001). Specimens of Palaeonictis from Abbey Wood in England and Pourcy in France are larger than P. gigantea and fall in the low end of the range of $P$. occidentalis (Hooker 1998).

A specimen identified here as $P$. wing $i$ was collected from a University of Michigan locality in the PETM (SC-67; Wa-0 biozone) along the southern tip of Polecat Bench in the Sand Coulee area west and north of Powell, Wyoming (Gingerich 1989). This specimen (UM 92889) was initially identified as an $\mathrm{M}_{2}$ of Palaeonictis sp. by Gingerich, who noted that it could belong to a new small species, or possibly belong to $P$. occidentalis or $P$. 
gigantea. UM 92889 is virtually identical to the $\mathrm{M}_{1}$ trigonid of UF 244450; the metaconid is robust and upright resulting in a less lingually open trigonid, and the trigonid is more similar in size to that of $\mathrm{M}_{1}$ than $\mathrm{M}_{2}$, so it is likely to be an $\mathrm{M}_{1}$ trigonid of $P$. wingi.

Conducting a robust phylogenetic analysis for species of Palaeonictis is complicated by a number of factors. As noted by Rose (1981), the overall morphology of the premolars and molars is quite similar among all species of Palaeonictis. Therefore, size is a primary diagnostic feature. Comparisons among species of Palaeonictis are further complicated by the fact that $P$. peloria, $P$. gigantea, and $P$. wingi are each represented primarily by one specimen. Most of the original French specimens of $P$. gigantea appear to be lost, and the most complete syntype (MNHN ARP 52) has been damaged and now only preserves the $\mathrm{P}_{3}, \mathrm{P}_{4}$ talonid, and $\mathrm{M}_{1}$ talonid (J. Hooker pers. comm., 2009). Thus, the original illustrations of P. gigantea (de Blaineville 1842) are the only source for evaluating certain morphological features. A phylogenetic analysis that incorporates $P$. wing $i$ and all other species of Palaeonictis is postponed until more material is described.

In summary, $P$. wing $i$ is similar to $P$. occidentalis, but differs from $P$. gigantea and $P$. peloria in having a more reduced $M_{2}$ relative to $M_{1}$, and having a smaller $M_{2}$ metaconid. Conversely, like $P$. gigantea and P. peloria, $P$. wingi lacks the apparently derived reduction of $P_{3}$ relative to $\mathrm{M}_{1}$ that is found in $P$. occidentalis. The only known Paleocene occurrence of Palaeonictis is P. peloria from the latest Clarkforkian of North America. We suggest that a form similar to P. peloria originated in North America and gave rise to two smaller forms during the PETM (Figure 4). The first probably dispersed eastward across a landbridge to give rise to $P$. gigantea in the earliest Eocene of Europe, and the second ( $P$. wingi) remained in North America (Figure 4). Palaeonictis gigantea retained the plesiomorphic condition of the molars, whereas the $M_{2}$ became more reduced in P. wingi. The dispersal of Palaeonictis to Europe would have coincided with rapid global warming of $5-10^{\circ} \mathrm{C}$, and related geographic range shifts in plants and other animals during the PETM (Gingerich 2003; Wing et al. 2005).

Although $P$. wing $i$ is smaller than the later occurring $P$. occidentalis, they are remarkably similar morphologically, and $P$. wingi likely gave rise to $P$. occidentalis following the PETM in North America. The only potential autapomorphy present in $P$. wing $i$ that could exclude it as an ancestor to P. occidentalis is the $3.5 \mathrm{~mm}$ diastema between $\mathrm{P}_{2}$ and $\mathrm{P}_{3}$. A diastema is variably present between $\mathrm{P}_{2}$ and $\mathrm{P}_{3}$ in $P$. occidentalis, although it is never as pronounced. Rose (1981) suggested that the variability of mandibular depth in P. occidentalis could be explained by sexual dimorphism. The presence and size of the diastema between $\mathrm{P}_{2}$ and $\mathrm{P}_{3}$ in $P$. wingi may also be related to sexual dimorphism, although larger sample sizes are needed to assess variability. If $P$. wingi gave rise to $P$. occidentalis following the PETM, then Palaeonictis became somewhat larger and underwent a reduction in the size of $\mathrm{P}_{3}$ relative to $\mathrm{M}_{1}$ in the early Eocene of North America.

The $\mathrm{P}_{4}$ of Palaeonictis from Dormaal in Belgium is smaller than that of the most complete syntype of $P$. gigantea, and may represent a new smaller species (Smith and Smith 2001). The Palaeonictis specimens from Abbey Wood in England and Pourcy in France are larger than those of $P$. gigantea and more similar in size to North American P. occidentalis (Hooker 1998). Considering that Dormaal appears to represent the PETM (Smith et al. 2006), and therefore older strata than Abbey Wood and Pourcy (Gingerich 1989; Hooker 1998), it is possible that a size increase in Palaeonictis occurred in the earliest Eocene of Europe, paralleling the size increase of the genus following the PETM in North America.

\section{Evolutionary "Dwarfing" during the PETM}

The early Wasatchian (Wa-0) vertebrate fauna from the northern Bighorn Basin was first described over two decades ago (Gingerich 1989). Small body size is a noticeable characteristic of many mammals occurring in Wa-0. Although not all mammalian lineages experienced a decrease in body size from Cf-3 to Wa0 , or an increase in body size from Wa-0 to Wa- 1 , no lineage exhibits a larger body size in Wa- 0 . When first described, the Wa-0 fauna included eleven small taxa with larger Cf-3 and/or Wa-1 congeneric species. Five of these species are the first records of genera that are characteristic of later Wasatchian faunas (Diacodexis, Hyracotherium, Cantius, Arfia, and Prolimnocyon), and thus were not considered dwarfed. The six other genera represented by a small species in Wa-0 are stratigraphically bracketed by a larger congener in the late Clarkforkian and early Wasatchian faunas (Ectocion, Copecion, Thryptacodon, Chriacus, Azygonyx, and Palaeanodon). Two of these six small species (Ectocion parous and Azygonyx gunnelli) were documented co-occurring with a larger congener in Wa-0, and Gingerich (1989) predicted that larger congeners would also be found co-occurring with the other four small species once the Wa-0 fauna was better known. The two co-occurrences of large and small congeneric species, and the fact that the other four large congeners were rare directly before and after Wa-0, suggested that in situ anagenetic dwarfing was unlikely, and the presence of small species in Wa- 0 could probably be explained by a change in sampling regime from low floodplains to high floodplains (Gingerich 1989). 

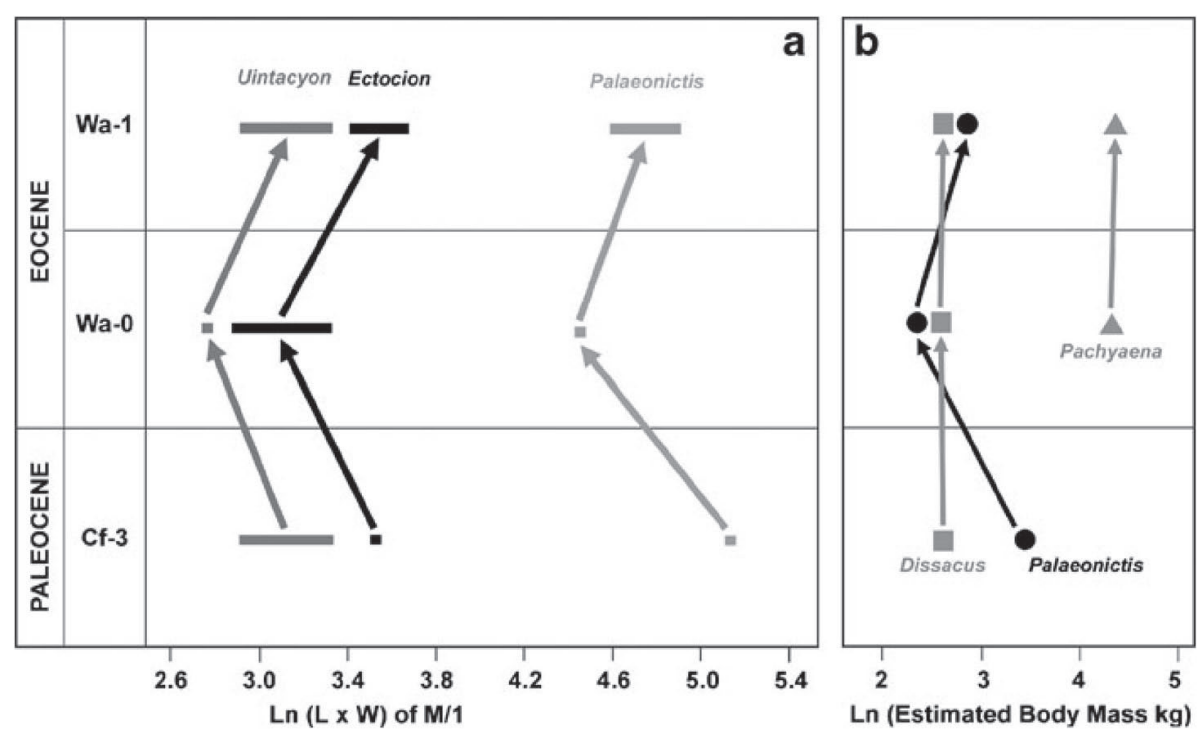

Figure 5. (a) Diagram illustrating herbivorous (e.g., Ectocion) and carnivorous (Uintacyon and Palaeonictis) mammals appearing to decrease approximately $50 \%$ in body size during the PETM. Rectangles represent range of values and squares represent one value. Arrows illustrate apparent shifts in body size over time. Values reported for Uintacyon rudis (Cf-3, Wa-1), and U. gingerichi (Wa-0) from Gingerich (1983) and Heinrich et al. (2008), respectively. All values reported for Ectocion represent specimens collected in Cabin Fork area. All values reported for Palaeonictis (right in lighter gray) represent measurements taken for this study. Faunal zones (Wa, Wasatchian; Cf, Clarkforkian) not to scale. All specimens binned in center of faunal zone. (b) Natural logarithm of estimated body mass of Palaeonictis, Dissacus, and Pachyaena from faunal zones Cf-3 to Wa-1. Estimates for Pachyaena are average values from Zhou et al. (1992) and O'Leary and Rose (1995). Estimates for other taxa are average values of regressions from Van Valkenburgh (1990) and Legendre (1986). See Table 2 for comparison of overall body size distribution of carnivorous taxa from Cf-3 to Wa-1 (not discussed in text). Palaeonictis peloria (Cf-3), Palaeonictis wingi (Wa-0), and Palaeonictis occidentalis (Wa-1) are represented by large black circles. Dissacus praenuntius (Cf-3 to Wa-1) and Pachyaena ossifraga (Wa-0 to Wa-1) are represented by large gray squares and triangles, respectively. Considerable decreases and increases in body size appear to occur in Palaeonictis, whereas mesonychids remain virtually unchanged.

In a more recent analysis, Gingerich (2003) considered the possibility that the larger genera co-occurring with smaller congeners in Wa-0 were contaminants from different faunal zones (see Wood et al. 2008), and that in situ anagenetic dwarfing could actually explain the reduced body size of many Wa-0 mammals. Body weights were estimated from tooth size (e.g., Gingerich and Smith 1984), and Gingerich concluded that taxa such as Ectocion osbornianus and Copecion brachypternus were briefly replaced by a congener approximately 50 $60 \%$ smaller (E. parvus and C. davisi, respectively) during the PETM. After determining that the observed shift in body size was not rate limited, Gingerich (2003) investigated which selective factors could be responsible for decreased body size, and considered elevated temperature and elevated $\mathrm{CO}_{2}$ levels as possibilities.

Bergmann's rule is the ecogeographical generalization that within a homeothermic vertebrate species, individuals from warm climates or lower latitudes tend to be smaller than those from colder climates or higher latitudes (Bergmann 1847; Rensch 1938; Mayr 1956). Koch (1986) studied clinal geographic variation in body size of five extant mammals to assess size change in the fossil record. Using regressions presented in this study, Gingerich (2003) estimated that the decrease in first lower molar crown area between Ectocion osbornianus (lat- est Paleocene) and E. parous (earliest Eocene) would require a $15^{\circ} \mathrm{C}$ increase in temperature. This number was considerably larger than previous estimates of temperature increase during the PETM (e.g., Fricke et al. 1998), and therefore Gingerich (2003) concluded that a reduction in body size in Wa-0 mammals could not solely be explained by Bergmann's rule. As a working hypothesis, Gingerich $(2003,2006)$ suggested that elevated atmospheric $\mathrm{CO}_{2}$ played an important role in the apparent dwarfing of herbivorous mammals by affecting the nutritional value and digestibility of plants. Studies have shown that herbivorous insects consuming leaves grown in $\mathrm{CO}_{2}$-enriched atmospheres grow more slowly (e.g., Tuchman et al. 2002). Gingerich (2003) concluded that similar affects may have slowed growth in mammals, leading to reproduction at a smaller body size, and environmental selection in favor of evolutionary dwarfing. As an alternative, he suggested that normalsized species may have been replaced by smaller congeners or other species.

Chester et al. (2005) reported several occurrences of small phenacodontid species (Ectocion parvus and Copecion davisi) previously known only from the PETM (Wa0 ) co-occuring with larger congeners (E. osbornianus and C. brachypternus) in the latest Clarkforkian (Cf-3) of the southern Bighorn Basin. As an alternative to the ana- 
genetic evolutionary dwarfing hypothesis, Chester et al. (2005) proposed that the larger phenacodontid species were temporarily replaced by smaller species due to shifting geographic range boundaries in response to warming. Evidence for shifting ranges in plants was documented by several palynomorphs and one leaf type also found in the Cabin Fork section. These plants migrated northward from the Gulf Coastal Plain and from Colorado during the PETM (Wing et al. 2005). This was consistent with the interpretation of Chester et al. (2005), because the range of the smaller phenacodontids may have shifted in response to northern extensions in the range of their environments.

We isotopically sampled the teeth of the Wa- 0 phenacodontid species recovered from the latest Clarkforkian in order to test whether these specimens were contaminents from the PETM. None of these specimens yielded $\delta^{13} \mathrm{C}$ values that would confidently place them below the CIE in the late Paleocene (Cf-3). A larger sample of Ectocion and Copecion teeth (Secord et al. 2009) that could be confidently assigned to Cf- 3 or Wa- 0 , show no overlap in $\delta^{13} \mathrm{C}$ values between pre-excursion and excursion values. Cf-3 values range from -12.0 to -7.0 (mean $=-9.9 \pm 3.0 \%$, $1.96 \mathrm{SD} ; n=20$ ), while CIE values range from -16.6 to $-12.9 \%$ o (mean $=-14.5 \pm 1.7 \%$, 1.96 $\mathrm{SD} ; n=26$ ). All but one of the anachronistic teeth fall within the range of excursion values $(-15.2 \%$, $-14.3 \%$, $-13.9 \%,-13.9 \%$ o, $-13.1 \%$, $-12.4 \%$ o). The single tooth that falls within the range of $\mathrm{Cf}-3$ values, identified as C. davisi (UF 246800 ), has a $\delta^{13} \mathrm{C}$ value of $-12.4 \%$, which is too negative to be confident that it is not a contaminent. Therefore, although the temporary replacement of larger species by smaller congeneric species could still be explained by a range shift in response to warming, the isotopic evidence is consistent with the idea that the smaller congeneric species documented in Cf- 3 are contaminants from $\mathrm{Wa}-0$, and there currently is no convincing evidence that refutes the evolutionary dwarfing hypothesis for these taxa.

Recently three new species of miacid carnivorans were described from Wa-0 (Heinrich et al. 2008). Like many other mammals from $\mathrm{Wa}-0$, these new species were smaller than other members of their respective genera. Criteria were established to assess whether these species fit the evolutionary dwarfing hypothesis, including: (1) the smaller species should only be found in Wa0 ; (2) the larger species should stratigraphically bracket the smaller species without co-occurring in Wa-0: and (3) the small and large species should be sister taxa and should have few, or no, morphological differences other than size (Heinrich et al. 2008). One of the three species, Uintacyon gingerichi, met these criteria, and is $50-60 \%$ of the body mass of its larger congener (U. rudis) based on the Van Valkenburgh (1990) regression of $M_{1}$ length and body mass in extant carnivorans (Heinrich et al. 2008). Uintacyon gingerichi is similar to previously documented "dwarfed" Wa-0 taxa in that it is $50-60 \%$ the body mass of its larger congener, but it differs in being a carnivorous mammal (Figure 5a).

Palaeonictis wingi is the second documented occurrence of a "dwarfed" carnivorous mammal from Wa-0 (Figure 5a). It does not meet all the criteria of Heinrich et al. (2008) for evolutionary dwarfing because it is not stratigraphically bracketed by the same larger species in Cf-3 and Wa-1. However, P. wingi only occurs in Wa-0, does not co-occur with a larger congener in Wa- 0 , and is stratigraphically bracketed by two larger congeneric species (P. peloria in Cf-3 and P. occidentalis in Wa-1) that have few morphological differences from $P$. wingi other than size. There is no reason that $P$. wingi would have to return to the same size as its late Paleocene congener in order to be considered dwarfed during the PETM. However, the presence of the same larger species temporally bracketing a smaller congeneric species is no better evidence for evolutionary dwarfing than it is for a shift in geographic range boundaries or the sampling of different environments.

The dental morphology of Palaeonictis wingi and Uintacyon gingerichi suggests that these mammals consumed meat and only had a small portion of vegetation in their diet. Although Palaeonictis was clearly capable of processing meat, it differs from many carnivorous mammals in having blunt-cusped teeth. This has led some researchers to suggest that Palaeonictis had a somewhat omnivorous or even durophagous diet (e.g., Rose 2006). The results of our dietary analysis suggest that Palaeonictis was not a strict "hypercarnivore" or "carnivore," but was probably an "animal-dominated omnivore" (Evans et al. 2007) (Figure 3). Results also suggest that Uintacyon had a similar diet to Palaeonictis. Palaeonictis and Uintacyon appear to have primarily relied on meat, so the reduction in body size documented in these taxa cannot entirely be explained by decreased nutritious quality of vegetation resulting from increases in atmospheric $\mathrm{CO}_{2}$. Moreover, modern mammals that consume vegetation with low nutrient content are typically larger than those that consume nutrient rich food, such as fruit and insects (e.g., Gaulin 1979). Thus, it is not clear that a $\mathrm{CO}_{2}$ induced decrease in the nutritional content of vegetation would directly result in a smaller body size in mammals, and it may even be expected to cause an increase in body size. These observations coupled with the fact that we know little about partial pressure of $\mathrm{CO}_{2}$ during the PETM (Gingerich 2003), indicates that we should consider additional possible selective factors for the smaller body size of mammals during the PETM.

The relationship between predator and prey body size has been well studied, and generally there is a strong correlation between predator size and average prey size (e.g., Rosenzweig 1966; Gittleman 1985; Radloff and Du Toit 2004). Larger carnivorous mammals 
Table 2. Summary of body mass estimates $(\mathrm{kg})$ of carnivorous mammals from Cf-3, Wa- 0 , and Wa- 1 faunal zones, based on regressions of lower first molar measurements (Legendre 1986; Van Valkenburgh 1990). Estimate type indicates how body size was estimated when $M_{1}$ measurements for a species in a particular faunal zone were not available: (1) $M_{1}$ measurements not known for a species in a faunal zone so $\mathrm{M}_{1}$ measurements of the same species from at least one other faunal zone used, (2) only one $\mathrm{M}_{1}$ dimension (i.e., either length or width) known for a species in a particular faunal zone so the other measurement was estimated based on $M_{1}$ proportions for the same species in at least one other faunal zone, (3) $M_{1}$ not known for a particular species in any faunal zone so $\mathrm{M}_{1}$ size estimated by comparing measurements of another molar position to that of a congener for which both $\mathrm{M}_{1}$ and the other molar position measurements were known.

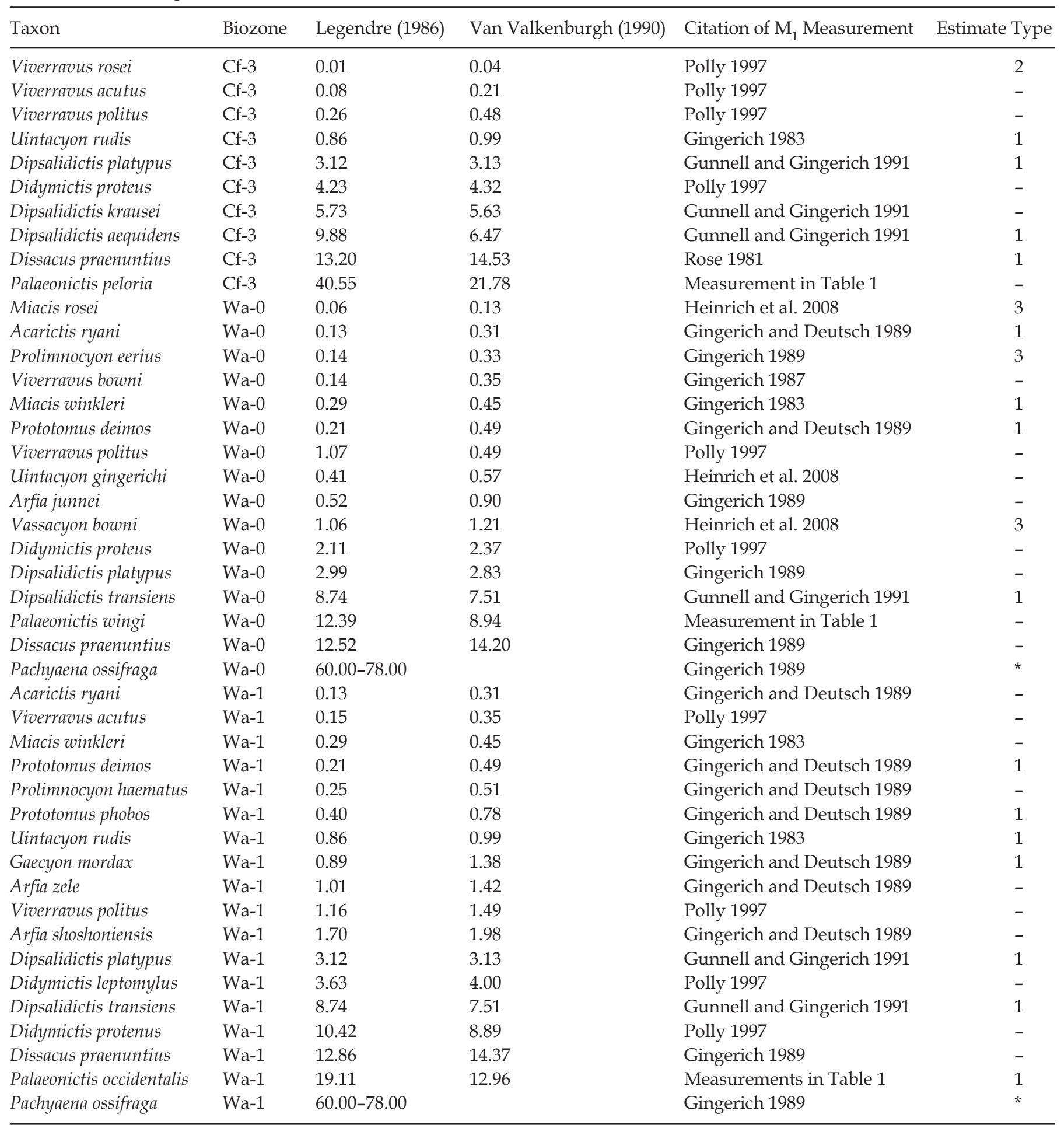

*For Pachyaena ossifraga, body size estimates were based on published body size estimates from postcranial measurements. Range for P. ossifraga reflects minimum estimate from Zhou et al. (1992) and maximum estimate from O'Leary and Rose (1995). 
tend to eat prey of larger size, although there are numerous exceptions to this trend (Rosenzweig 1966). Across Carnivora, large species feed on all different sizes of prey, but smaller species are limited to smaller prey (Schoener 1969; Gittleman 1985; Radloff and Du Toit 2004). However, the ecological effect of limiting a predator to prey that are smaller on average than those it is adapted to consume is unknown. It is possible that such a situation would be energetically inefficient and select for smaller body size in the predator. Some evidence for predator body size change in response to changes in prey size comes from a study by Schmitz and Lavinge (1987), in which body size and dietary habits of sympatric wolves and coyotes in southeastern Ontario were documented over time. During the study period, wolves decreased in mean body length, which was correlated with a decrease in prey size. Coyotes increased in average body mass and head-body length, which did not appear to be related to changes in the size of their prey, but could have been related to an increase in food supply. Schmitz and Lavinge (1987) concluded that changes in size were not necessarily related to competition between these predators, but were likely the result of selection caused by the size and abundance of prey. Palaeonictis was one of the largest mammalian predators in the latest Paleocene and earliest Eocene of North America, so it was probably able to focus on a large size range of prey. Some of the most abundant herbivore genera (and potential prey) in Wa-0, such as Ectocion and Copecion, were considerably larger in the latest Paleocene. Therefore, it seems reasonable that Palaeonictis may have decreased in body size in response to the reduced average size of its mammal prey during the PETM.

The hypothesis that PETM predators decreased in size due to decreases in prey size could be tested by looking at more strictly carnivorous mammals to see if they exhibit a similar pattern of body size change. Our dietary analysis suggests that the mesonychid Dissacus was significantly more focused on meat than Palaeonictis and Uintacyon. Unlike Palaeonictis and Uintacyon, the same species of Dissacus occurred across the PaleoceneEocene boundary, so Dissacus does not appear to have experienced a dietary shift or a decrease in body size during the PETM. Superficially, this seems to refute the idea that decreased body size in prey animals was functionally linked to decreased body size in PETM predators. However, evidence points to the possibility that the ecological niche of Dissacus was fundamentally different from "animal dominated omnivores" like Palaeonictis and Uintacyon. Mesonychids are often reconstructed as hyaena-like carrion feeders based on dental and postcranial morphology (e.g., Zhou et al. 1992). If predator size is correlated to prey size through energetics involved in the pursuit of prey, scavengers would not be expected to follow these rules as their prey does not need to be chased or killed.
More evidence regarding ecological similarities and differences between Palaeonictis, Dissacus, and other carnivorous mammals comes from a consideration of body size distributions and changes among carnivorous mammals through the PETM. Palaeonictis peloria is the largest carnivorously-adapted mammal known from the Clarkforkian (Rose 1981). The second and third largest carnivorous mammals known from Cf-3 (mesonychid Dissacus praenuntius and oxyaenid Dipsalidictis aequidens, respectively) were not nearly as large as P. peloria. Palaeonictis wingi, however, is not the largest carnivorous mammal known from the PETM. Body size estimates for $P$. wingi (Table 2) show that it was considerably smaller than the mesonychid Pachyaena ossifraga, which first appears in the PETM (Gingerich 1989), and it was slightly smaller than Dissacus praenuntius. Pachyaena ossifraga was much larger than any other carnivorous mammal known from the earliest Eocene (Figure 5b; Table 2).

The relationship between competition and body size among carnivorous mammals has been investigated by many researchers (e.g., Rosenzweig 1966, 1968a; Kiltie 1984; Schmitz and Lavinge 1987). It has been suggested that sympatric carnivores coexist in part due to maintaining different body sizes, and absence of a particular body size may create a selective force that would lead other carnivores to fill that niche (Rosenzweig 1966, 1968a). This size difference would in turn lead each predator to utilize a different sized set of prey (Rosenzweig 1966). Unlike Uintacyon, which was one of many small carnivorous mammals present in Cf-3, Wa-0, and Wa-1 (Table 2), Palaeonictis was one of the largest carnivorous mammals present during this interval, so it is easier to consider which other carnivorous mammals it may have been in competition with. Although it is speculative to infer competition in the fossil record, the fact that Palaeonictis decreases body size and appears to have crossed the body size range of sympatric large-bodied Dissacus during the PETM suggests that they likely were not competing for food resources (Figure 5b; Table 2). If their respective ecological niches were different, then the environmentally related mechanism that caused body size change in Palaeonictis was plausibly inapplicable to Dissacus. There is no clear evidence for competition between Palaeonictis and any similar-sized predator in Cf-3 (Table 2), so competition probably was not a selective force for decreased body size in Palaeonictis during the PETM.

Bergmann's rule is now generally accepted for mammals as a whole and when broken down into orders or families, although numerous exceptions have been recognized (Ashton et al. 2000). As mentioned above, Gingerich (2003) used regressions from Koch (1986) to estimate the amount of temperature change needed to produce the observed body size changes in Ectocion during the PETM, and concluded that Bergmann's rule could not completely explain this pattern. It should 
be noted that this is only true if the correction used by Koch (1986) for differences in the latitudinal temperature gradient is correct (i.e., if Eocene temperature gradients were approximately one-half as steep as they are today), and if the five extant taxa chosen for this study reflect a similar range of body size change along latitudinal clines for early Wasatchian mammals. Also, continental temperature change during the PETM is difficult to reconstruct, associated with large error (Koch et al. 2003; Wing et al. 2005), and could have been greater in intercontinental basins than in the marine realm. Regardless, if Bergmann's rule does not fully explain the changes in body size during the PETM, increased temperature still probably played a role in the decreased size of Wa-0 mammals. Mammalian carnivores tend to have large geographical ranges and often show geographical size variation, so they have been used quite often to test Bergmann's rule (Meiri et al. 2004). Past studies have shown that temperature and latitude are good predictors of body size among carnivores (e.g., Rosenweig 1968a). A recent study analyzed more than one fourth of extant carnivore species and demonstrated that approximately half of these carnivores appear to follow Bergmann's rule (Meiri et al. 2004). These data along with new insights on the relationship between climate change during the PETM and body size trends in Hyracotherium (Secord et al. 2008), suggest that increased temperature played a role in the decreased size of Palaeonictis and other mammals during the PETM. The increase in temperature may have also indirectly affected carnivore body size by affecting the size of their prey.

Lastly, animals need a sufficient rate of food supply in order to maintain a body size, and when food is scarce, natural selection may modify body size in relation to levels of productivity (Rosenzweig 1968a). Actual evapotranspiration (AE) is the quantity of water entering the atmosphere from the soil and vegetation during a period of time. AE has been demonstrated to be a highly significant estimator of net primary productivity in mature terrestrial plant communities, probably because it measures the availability of water and solar energy (Rosenzweig 1968b). Rosenzweig (1968a) found that primary productivity was a good predictor of body size among mammalian carnivores, especially at lower productivity levels. This is probably because body size is limited by the scarcity of food in environments lacking in water and/or heat (Rosenzweig 1968a). Although several studies have proposed an increase in precipitation during the PETM (e.g., Koch et al. 2003; Shellito et al. 2003; Bowen et al. 2004), more recent studies have suggested a noticeable decrease in precipitation at the onset of the PETM (Wing et al. 2005; Kraus and Riggins 2007). Wing et al. (2005) used two methods of leaf area analysis to estimate average annual precipitation for two PETM fossil floras in the southern Bighorn Basin. The locality at the base of the PETM indicated a $\sim 40 \%$ decline of rainfall near the onset of the PETM, and the locality representing the later part of the PETM indicated a return to wetter conditions. Kraus and Riggins (2007) analyzed paleosols from the PETM and also demonstrated that precipitation decreased markedly at the onset of the PETM and returned to pre-PETM levels by the end of the CIE. The decrease of precipitation at the onset of the PETM would have decreased levels of productivity, and may be partially responsible for the decrease in the body size of both carnivorous and herbivorous mammals during this interval.

In summary, there is currently no compelling evidence to refute the evolutionary dwarfing hypothesis, although apparent dwarfing during the PETM may actually be the result of larger species being temporarily replaced by smaller species due to shifting geographic range boundaries in response to warming (Gingerich 1989, 2003; Chester et al. 2005; Beard and Dawson 2009). However, assuming evolutionary dwarfing explains some or all of these patterns, we suggest the following: (1) increased $\mathrm{CO}_{2}$ levels were not the direct cause of dwarfing in carnivorous mammals during the PETM, but the decreased body size of some carnivores may be partially explained as a response to the decreased size of their herbivorous mammal prey, (2) competition with sympatric predators does not seem to explain the reduced body size of at least Palaeonictis during the PETM, and (3) selective pressures such as increased temperature and aridity contributed to the dwarfing of carnivorous and herbivorous mammals during this interval.

Acknowledgments - For access to specimens, we thank Walter Joyce and Daniel Brinkman, Division of Vertebrate Paleontology, Peabody Museum of Natural History, New Haven; John Flynn and Judith Galkin, Department of Vertebrate Paleontology, American Museum of Natural History, New York; Richard Hulbert, Division of Vertebrate Paleontology, Florida Museum of Natural History, Gainesville; Philip Gingerich and Gregg Gunnell, Museum of Paleontology, University of Michigan; and Jerry Hooker, Natural History Museum, London. We thank John Wible and two anonymous reviewers for comments that improved the manuscript. We thank Gregg Gunnell, Scott Wing, Jerry Hooker, Richard Hulbert, John Krigbaum, Mary Kraus, Francesca McInerney, Paul Koch, David Fox, and Eric Sargis for helpful discussions. We also thank Jason Bourque and Alex Hastings for preparation of specimens. Research was funded by grants from NSF EAR-0640076 (J.I.B., R.S., and J.S. Krigbaum) and NSF EAR-0719941 (J.I.B., F. McInerney, S.L. Wing, and M.J. Kraus), and the Yale Institute for Biospheric Studies Center for Field Ecology to S.G.B.C. This support is gratefully acknowledged.

\section{References}

Ashton KG, Tracy MC, de Queirox A (2000) Is Bergmann's rule valid in mammals? Am Nat 156:390-415

Beard KC (2008) The oldest North American primate and mammalian biogeography during the Paleocene-Eocene Thermal Maximum. Proc Natl Acad Sci USA 105:3815-3818 
Beard KC, Dawson MR (2009) Early Wasatchian mammals of the Red Hot Local Fauna, uppermost Tuscahoma Formation, Lauderdale County, Mississippi. Ann Carnegie Mus 78:193-243

Bergmann C (1847) Uber die Verhaltnisse der Warmeokonomie der Thiere zu ihrer Grosse. Gottinger Stud 31:595-708

Bowen GJ, Beerling DJ, Koch PL, Zachos JC, Quattlebaum T (2004) A humid climate state during the Palaeocene/Eocene thermal maximum. Nature 432:495-499

Bowen GJ, Clyde WC, Koch PL, Ting S, Alroy J, Tsubamoto T, Wang Y, Wang Y (2002) Mammalian dispersal at the Paleocene/Eocene boundary. Science 295:2062-2065

Bowen GJ, Koch PL, Gingerich PD, Norris RD, Bains S, Corfield RM (2001) Refined isotope stratigraphy across the continental Paleocene-Eocene boundary on Polecat Bench in the northern Bighorn Basin. In: PD Gingerich (ed) Paleocene-Eocene Stratigraphy and Biotic Change in the Bighorn and Clarks Fork basins, Wyoming. Univ Mich Pap Paleontol 33:73-88

Boyer DM (2008) Relief index of second mandibular molars is a correlate of diet among prosimian primates and other euarchontan mammals. J Hum Evol 46:605-622

Chester SGB, Bloch JI, Boyer DM, Wing SL (2005) Anachronistic occurrences of phenacodontid species in the Clarkforkian of the southern Bighorn Basin: Possible evidence against transient dwarfing in Ectocion and Copecion during the CIE-PETM interval. J Vertebr Paleontol 25:44A

Clyde WC, Gingerich PD (1998) Mammalian community response to the latest Paleocene thermal maximum: An isotaphonomic study in the northern Bighorn Basin, Wyoming. Geology 26:1011-1014

Cope ED (1877) Report upon the extinct Vertebrata obtained in New Mexico by parties of the expedition of 1874. Geogr Surv West 100th Mer 4:1-370

Cope ED (1878) Excursion de Meudon. Bull Soc Geol France, ser 3, 6:661-663

de Blaineville HMD (1842) Ostéographie ou description iconographique comparée du squelette et du système dentaire des mammifères récents et fossiles pour servir de base à la zoologie et à la géologie. Livraison 10: Des Viverras. J.B. Baillière et Fils, Paris: $1-100$

Denison RH (1938) The broad-skulled Pseudocreodi. Ann NY Acad Sci 37:163-256

Eberle JJ, McKenna MC (2002) Early Eocene Leptictida, Pantolesta, Creodonta, Carnivora, and Mesonychidae (Mammalia) from the Eureka Sound Group, Ellesmere Island, Nunavut. Can J Earth Sci 39:899-910

Evans AR, Wilson GP, Fortelius M, Jernvall J (2007) High-level similarity of dentitions in carnivorans and rodents. Nature 445:78-81

Fricke HC, Clyde WC, O'Neil JR, Gingerich PD (1998) Evidence for rapid climate change in North America during the latest Paleocene thermal maximum: Oxygen isotope compositions of biogenic phosphate from the Bighorn Basin (Wyoming). Earth Planet Sci Lett 160:193-208

Gaulin, SJC (1979) A Jarman/Bell model of primate feeding niches. Hum Ecol 7:1-20

Gingerich PD (1980) Tytthaena parrisi, oldest known oxyaenid (Mammalia, Creodonta) from the late Paleocene of western North America. J Paleontol 54:570-576

Gingerich PD (1983) Systematics of early Eocene Miacidae (Mammalia, Carnivora) in the Clark's Fork Basin, Wyoming. Contrib Mus Paleontol Univ Mich 26:197-225

Gingerich PD (1987) Early Eocene bats (Mammalia, Chiroptera) and other vertebrates in freshwater limestones of the Willwood Formation, Clarks Fork Basin, Wyoming. Contrib Mus Paleontol Univ Mich 27:275-320

Gingerich PD (1989) New earliest Wasatchian mammalian fauna from the Eocene of northwestern Wyoming: Composition and diversity in a rarely sampled high-floodplain assemblage. Univ Mich Pap Paleontol 28:1-97

Gingerich PD (2003) Mammalian responses to climate change at the Paleocene-Eocene boundary: Polecat Bench record in the northern Bighorn Basin, Wyoming. In: Wing SL, Gingerich PD, Schmitz B, Thomas E (eds) Causes and Consequences of Globally Warm Climates in the Early Paleogene. Geol Soc Am Spec Pap 369:463-478

Gingerich PD (2006) Environment and evolution through the Paleocene-Eocene thermal maximum. Trends Ecol Evol 21:246-253

Gingerich PD, Deutsch HA (1989) Systematics and evolution of early Eocene Hyaenodontidae (Mammalia, Creodonta) in the Clarks Fork Basin, Wyoming. Contrib Mus Paleontol Univ Mich 27:327-391

Gingerich PD, Smith BH (1984) Allometric scaling in the dentition of primates and insectivores. In: Jungers WL (ed) Size and Scaling in Primate Biology. Plenum Publishing Corp, New York, pp 257-272

Gingerich PD, Smith TS (2006) Paleocene-Eocene land mammals from three new latest Clarkforkian and earliest Wasatchian wash sites at Polecat Bench in the northern Bighorn Basin, Wyoming. Contrib Mus Paleontol Univ Mich 31:245-303

Gittleman JL (1985) Carnivore body size: Ecological and taxonomic correlates. Oecologia 67:540-554

Gunnell GF (1998) Creodonta. In: CM Janis, KM Scott, and LL Jacobs (eds) Evolution of Tertiary Mammals of North America. Volume 1: Terrestrial Carnivores, Ungulates, and Ungulatelike Mammals. Cambridge University Press, Cambridge, pp 91-109

Gunnell GF, Gingerich PD (1991) Systematics and evolution of late Paleocene and early Eocene Oxyaenidae (Mammalia, Creodonta) in the Clarks Fork Basin, Wyoming. Contrib Mus Paleontol Univ Mich 28:141-180

Heinrich RE, Strait SG, Houde P (2008) Earliest Eocene Miacidae (Mammalia: Carnivora) from northwestern Wyoming. J Paleontol 82:154-162

Hooker JJ (1998) Mammalian faunal change across the PaleoceneEocene transition in Europe. In: M Aubry, SG Lucas, and WA Berggren (eds) Late Paleocene-Early Eocene Climatic and Biotic Events in the Marine and Terrestrial Records. Columbia University Press, New York, pp 428-450

Kihm AJ (1984) Early Eocene mammalian faunas of the Piceance Creek Basin Northwestern Colorado. Ph.D. Thesis, University of Colorado, Boulder, pp 1-381

Kiltie RA (1984) Size ratios among sympatric neotropical cats. Oecologia 61:411-416

Koch PL (1986) Clinal geographic variation in mammals: Implications for the study of chronoclines. Paleobiology 12:261-281

Koch PL, Clyde WC, Hepple RP, Fogel ML, Wing SL, Zachos JC (2003) Carbon and oxygen isotope records from paleosols spanning the Paleocene-Eocene boundary, Bighorn Basin, Wyoming. In: SL Wing, PD Gingerich, B Schmitz, E Thomas (eds) Causes and Consequences of Globally Warm Climates in the Early Paleogene. Geol Soc Am Spec Pap 369:49-64

Koch PL, Zachos JC, Gingerich PD (1992) Correlation between isotope records in marine and continental carbon reservoirs near the Palaeocene-Eocene boundary. Nature 358:319-322

Kraus MJ, Riggins S (2007) Transient drying during the PaleoceneEocene Thermal Maximum (PETM): Analysis of paleosols in the bighorn basin, Wyoming. Palaeogeogr Palaeoclimatol Palaeoecol 245:444-461

Legendre S (1986) Analysis of mammalian communities from the late Eocene and Oligocene of southern France. Palaeovertebrata 16:191-212

Mayr E (1956) Geographical character gradients and climatic adaptation. Evolution 10:105-108

Meiri S, Dayan T, Simberloff D (2004) Carnivores, biases, and Bergmann's rule. Biol J Linn Soc 81:579-588 
O'Leary MA, Rose KD (1995) Postcranial skeleton of the early Eocene mesonychid Pachyaena (Mammalia: Mesonychia). J Vertebr Paleontol 15:410-430

Ogg JG, Smith AG (2004) The geomagnetic polarity time scale. In: Gradstein FM, Ogg JG, Smith AG (eds) A Geologic Time Scale. Cambridge University Press, Cambridge, pp 63-86

Polly PD (1997) Ancestry and species definition in paleontology: A stratocladistic analysis of Paleocene-Eocene Viverravidae (Mammalia, Carnivora) from Wyoming. Contrib Mus Paleontol Univ Mich 30:1-53

Quinet GE (1966) Les mammifères du Landénien continental belge, second tome. Etude de la morphologie dentaire comparée des carnivores de Dormaal. Mém Inst R Sci Nat Belg 158:1-64

Radloff FGT, Du Toit JT (2004) Large predators and their prey in a southern African savanna: A predator's size determines its prey size range. J Anim Ecol 73:410-423

Rensch B (1938) Some problems of geographical variation and species-formation. Proc Linn Soc Lond 150:275-285

Rose KD (1981) The Clarkforkian Land-Mammal Age and mammalian faunal composition across the Paleocene-Eocene boundary. Univ Mich Pap Paleontol 26:1-197

Rose KD (2006) The Beginning of the Age of Mammals. The Johns Hopkins University Press, Baltimore

Rosenzweig ML (1966) Community structure in sympatric Carnivora. J Mammal 47:602-612

Rosenzweig ML (1968a) The strategy of body size in mammalian carnivores. Am Midl Nat 80:299-315

Rosenzweig ML (1968b) Net primary productivity of terrestrial communities: Prediction from climatological data. Am Nat 102:67-74

Schmitz OJ, Lavinge DM (1987) Factors affecting body size in sympatric Ontario Canis. J Mammal 68:92-99

Schoener TW (1969) Models of optimal size for solitary predators. Am Nat 103:277-313

Secord R (2008) The Tiffanian land-mammal age (middle and late Paleocene) in the northern Bighorn Basin, Wyoming. Univ Mich Pap Paleontol 35:1-192

Secord R, Bloch JI, Boyer DM, Chester SGB, Krigbaum J (2009) A new high-resolution continental record of the Paleocene-Eocene boundary carbon isotope excursion from mammalian tooth enamel. Geol Soc Am Abstracts w Programs 41:567

Secord R, Chester SGB, Bloch JI, Boyer DM, Krigbaum J (2008) The first North American equids: A high-resolution stratigraphic study in the Paleocene-Eocene thermal maximum. J Vertebr Paleontol 28:140A

Secord R, Gingerich PD, Smith ME, Clyde WC, Wilf P, Singer BS (2006) Geochronology and mammalian biostratigraphy of middle and upper Paleocene continental strata, Bighorn Basin, Wyoming. Am J Sci 306:211-245

Shellito CJ, Sloan LC, Huber M (2003) Climate model sensitivity to atmospheric CO2 levels in the early-middle Paleogene. Palaeogeogr Palaeoclimatol Palaeoecol 193:113-123

Sluijs A, Schouten S, Pagani M, Woltering M, Brinkhuis H, Damsté JSS, Dickens GR, Huber M, Reichart G-J, Stein R, Matthiessen J, Lourens LJ, Pedentchouk N, Backman J, Moran K, Clemens S, Cronin T, Eynaud F, Gattacceca J, Jakobsson M, Jordan R, Kaminski M, King J, Koc N, Martinez NC, McInroy D, Moore TC Jr, O’Regan M, Onodera J, Palike H, Rea B, Rio D, Sakamoto T, Smith DC, St John KEK, Suto I, Suzuki N, Takahashi K, Watanabe M, Yamamoto M (2006) Subtropical Arctic Ocean temperatures during the Palaeocene/Eocene thermal maximum. Nature 441:610-613

Smith FA, Wing SL, Freeman KH (2007) Magnitude of the carbon isotope excursion at the Paleocene-Eocene thermal maximum: The role of plant community change. Earth Planet Sci Lett 262:50-65
Smith JJ, Hasiotis ST, Kraus MJ, Woody DT (2009) Transient dwarfism of soil fauna during the Paleocene-Eocene thermal maximum. Proc Natl Acad Sci USA 106:17655-17660

Smith R, Hooker JJ (1996) Sur la présence de dents de mammifères (Creodonta, Perissodactyla) près de la limite Paléocène-Eocène à Hoegaarden, Belgique. Palaeovertebrata 25:115-124

Smith T (2000) Mammals from the Paleocene-Eocene transition in Belgium (Tienen Formation, MP7): Palaeobiogeographical and biostratigraphical implications. Geol Foren Stock For 122:148-149

Smith T, Smith R (2001) The creodonts (Mammalia, Ferae) from the Paleocene-Eocene transition in Belgium (Tienen Formation MP7). Belg J Zool 131:117-135

Smith T, Bloch JI, Strait SG, Gingerich PD (2002) New species of Macrocranion (Mammalia, Lipotyphla) from the earliest Eocene of North America and its biogeographic implications. Contrib Mus Paleontol Univ Mich 30:373-384

Smith T, Rose KD, Gingerich PD (2006) Rapid Asia-Europe-North America geographic dispersal of earliest Eocene primate Teilhardina during the Paleocene-Eocene Thermal Maximum. Proc Natl Acad Sci USA 103:11223-11227

Teilhard de Chardin P (1922) Les mammifères de l'éocène inférieur français et leurs gisements. Ann Paléontol 10:1-114

Thomas DJ, Zachos JC, Bralower TJ, Thomas E, Bohaty S (2002) Warming the fuel for the fire: Evidence for the thermal dissociation of methane hydrate during the Paleocene-Eocene thermal maximum. Geology 30:1067-1070

Tuchman NC, Wetzel RG, Rier ST, Wahtera KA, Teeri JA (2002) Elevated atmospheric $\mathrm{CO}_{2}$ lowers leaf litter nutritional quality for stream ecosystem food webs. Glob Change Biol 8:163-170

Van Valkenburgh B (1990) Skeletal and dental predictors of body mass in carnivores. In: Damuth J, MacFadden BJ (eds) Body Size in Mammalian Paleobiology. Cambridge University Press, Cambridge, pp 181-205

Westerhold T, Rohl U, McCarren HK, Zachos JC (2009) Latest on the absolute age of the Paleocene-Eocene Thermal Maximum (PETM): New insights from exact stratigraphic position of key ash layers +19 and -17. Earth Planet Sci Lett 287:412-419

Wing SL, Bloch JI, Bowen GJ, Boyer DM, Chester SGB, Diefendorf AF, Harrington GJ, Kraus MJ, Secord R, McInerney FA (2009). Coordinated sedimentary \& biotic change during the Paleocene Eocene Thermal Maximum in the Bighorn Basin, Wyoming, USA. In: EM Crouch, CP Strong, and CP Hollis (eds) Climatic and Biotic Events of the Paleogene (CBEP 2009), extended abstracts from an international conference in Wellington, New Zealand, 12-15 January 2009. GNS Sci Misc Ser 18:157-163

Wing SL, Harrington GJ, Smith FA, Bloch JI, Boyer DM, Freeman $\mathrm{KH}$ (2005) Transient floral change and rapid global warming at the Paleocene-Eocene boundary. Science 310:993-996

Wood AR, Krause MJ, Gingerich PD (2008) Downslope fossil contamination: Mammal-bearing fluvial conglomerates and the Paleocene-Eocene transition (Willwood Formation, Bighorn Basin, Wyoming). Palaios 23:380-390

Yans J, Strait SG, Smith T, Dupuis C, Steurbaut E, Gingerich PD (2006) High-resolution carbon isotope stratigraphy and mammalian faunal change at the Paleocene-Eocene boundary in the Honeycombs area of the southern Bighorn Basin, Wyoming. Am J Sci 306:712-735

Zachos JC, Wara MW, Bohaty S, Delaney ML, Rose Petrizzo M, Brill A, Bralower TJ, Premoli-Silva I (2003) A transient rise in tropical sea surface temperature during the Paleocene-Eocene Thermal Maximum. Science 302:1551-1554

Zhou X, Sanders WJ, Gingerich PD (1992) Functional and behavioral implications of vertebral structure in Pachyaena ossifraga (Mammalia, Mesonychia). Contrib Mus Paleontol Univ Mich 28:289-319 